\title{
PENERAPAN METODE PEMBELAJARAN MODEL JIGSAW TERHADAP MOTIVASI DAN HASIL BELAJAR
}

\section{Ester Fajarita Kristanti}

Universitas Kristen Satya Wacana, Salatiga, Jawa Tengah, Indonesia

Email: esterfajarita96@gmail.com

\begin{tabular}{l}
\hline INFO ARTIKEL \\
\hline Diterima \\
5 April 2021 \\
Direvisi \\
10 April 2021 \\
Disetujui \\
15 April 2021 \\
\hline
\end{tabular}

Keywords:

learn cooperative jigsaw model; learning; learning outcomes

\begin{abstract}
This study aims to improve students' motivation and learning outcomes, in economics subjects with management subjects and operating systems in Indonesia class X IPS 3 through cooperative learning methods jigsaw model at SMA Kristen 1 Salatiga. This type of research is a class action research conducted with one cycle with stages of planning, implementation, observation and reflection. This research is a collaborative study, where teachers act as executors and researchers as obsever. The subject of this class action research is grade X IPS 3 students and the object of this class action research is the motivation and learning outcomes of students in class X economics subjects with management subjects and operating systems in Indonesia through the application of cooperative defense methods jigsaw model. The data collection instrument in this research uses observation sheets, questionnaires, and documentation of activities conducted by each meeting. The data of this study was analyzed descriptively kuntitatif. The result of the study suggest that the apllication of jigsaw cooperative learning methods can increase motivation and student's study result. It is marked after the performance of the sizeweed 1, the motivation for student learning increase, the student becomes more familiar with the material and gets better result. The studentalso has an improvenent, which is marked by an average of 80,92 with a learned precentage of $82,14 \%$ of those prevously only up to 74,14 with a benchmark precentage of $60,71 \%$.
\end{abstract}

\section{ABSTRAK}

Penelitian ini bertujuan untuk meningkatkan motivasi dan hasil belajar siswa, pada mata pelajaran ekonomi dengan pokok bahasan manajemen dan sistem pengkoperasian di Indonesia kelas X IPS 3 melalui metode pembelajaran koperatif model jigsaw di SMA Kristen 1 Salatiga. Jenis

$\begin{array}{ll}\text { How to cite: } & \text { Kristanti, Ester Fajarita (2021) Penerapan Metode Pembelajaran Model Jigsaw Terhadap Motivasi } \\ & \text { Dan Hasil Belajar. Jurnal Syntax Admiration 2(4). https://doi.org/10.46799/jsa.v2i4.217 } \\ \text { E-ISSN: } & \frac{2722-5356}{\text { Ridwan Institute }} \\ \text { Published by: } & \text { Ridis }\end{array}$




\section{Kata Kunci:}

pembelajaran kooperatif model jigsaw; motivasi belajar; hasil belajar penelitian ini adalah penelitian tindakan kelas yang dilakukan dengan satu siklus dengan tahapan perencanaan, pelaksanaan, pengamatan dan refleksi. Penelitian ini merupakan penelitian kolaborasi, dimana guru bertindak sebagai pelaksana dan peneliti sebagai obsever. Subjek penelitian tindakan kelas ini adalah siswa kelas X IPS 3 dan objek penelitian tindakan kelas ini adalah motivasi dan hasil belajar siswa pada mata pelajaran ekonomi kelas $\mathrm{X}$ dengan pokok bahasan manjemen dan sistem pengkoperasian di Indonesia melalui penerapan metode pembelaran kooperatif model jigsaw. Instrument pengumpulan data dalam penelitian ini menggunakan lembar observasi, lembar angket, dan dokumentasi kegiatan yang dilakukan setiap pertemuan. Data hasil penelitian ini dianalisis secara deskriptif kuantitatif. Hasil penelitian ini menunjukkan bahwa penerapan metode pembelajaran model jigsaw dapat meningkatkan motivasi dan hasil belajar siswa. Hal tersebut ditandai setelah diadakannya siklus I, motivasi belajar siswa menigkat, siswa menjadi lebih memahami materi dan mendapatkan hasil yang lebih baik. Hasil belajar siswa juga mengalami peningkatan, yaitu ditandai dengan rata- rata hasil belajar yang dicapai yaitu sebesar 80,92 dengan presentase ketuntasan belajar sebesar $82,14 \%$ dari yang sebelumnya hanya mencapai 74,14 dengan presentase ketuntasan sebesar $60,71 \%$.

\section{Pendahuluan}

Pendidikan merupakan metode kegiatan belajar mengajar secara langsung yang dilaksanakan di dalam ruangan ataupun di luar ruangan yang bertujuan untuk meningkatkan kepandaian (Anwar, 2015). Berdasarkan UU No. 20 tahun 2003 mengenai sistem pendidikan nasional menyatakan bahwa pendidikan adalah usaha sadar yang sudah direncanakan untuk menciptakan suasana belajar dan proses pembelajaran supaya siswa bisa aktif menumbuhkan potensi yang ada dalam dirinya agar memiliki kegiatan spiritual keagamaan, pengendalian diri, kepribadian, kecerdasan, akhlak mulia, dan juga keterampilan yang dibutuhkan oleh masyarakat (Noor, 2018). Pendidikan juga merupakan factor kunci utama yang memegang peranan terbesar dalam kemajuan suatu bangsa dan peradaban. Pendidikan tidak hanya sekedar membentuk kecerdasan suatu bangsa, tapi juga ikut membentuk suatu watak dan karakter yang kuat dari bangsa tersebut (Saputra, 2016).

Menurut Kimble serta Garmezy dalam (Rohaeni, 2020) pembelajaran adalah suatu perubahan perilaku yang relatif tetap dan merupakan hasil praktik yang dilakukan. Pembelajaran juga mempunyai makna bahwa subjek atau siswa harus dibelajarkan bukan diajarkan. Siswa dituntut untuk aktif mencari, menganalisis, menemukan, 
memecahkan masalah dan menyimpulkan suatu masalah (Huda \& Pembelajaran, 2014). Dalam kegiatan proses pembelajaran ada korelasi antara siswa dan guru serta sumber belajar di lingkungan tersebut. Pengajaran bisa diartikan sebagai praktek yang membagikan informasi dalam proses kegiatan pembelajaran untuk membentuk pengalaman dalam belajar, baik dalam memberikan informasi ataupun dalam memotivasi peserta didik (Parnawi, 2019).

Dalam kegiatan pembelajaran motivasi adalah hal penting, karena itu guru mempunyai peranan penting untuk memotivasi siswanya. Menurut Mc. Donald dalam (Sardiman, 2014) motivasi adalah perubahan energi dalam diri seseorang yang ditandai dengan munculnya "feeling" dan didahului dengan tanggapan terhadap adanya tujuan. Motivasi belajar adalah faktor psikis yang bersifat non-intelektual. Peran khasnya adalah tumbuhnya gairah, merasa senang dan semangat untuk belajar. Motivasi juga mempengaruhi hasil belajar siswa. Siswa yang mempunyai motivasi yang kuat akan semangat untuk belajar dan hasil belajarnya pun sudah pasti akan memuaskan, namun sebaliknya siswa yang motivasinya rendah maka tidak akan mempunyai gairah untuk semangat belajar dan hasil belajarnya pun pasti akan rendah juga (Aunurrahman et al., 2017).

Tujuan utama yang akan dicapai dalam pembelajaran adalah hasil belajar. Hasil belajar digunakan untuk melihat sejauh mana siswa tersebut dapat memahami materi pelajaran yang telah diberikan. Menurut (Syamsi, 2010) hasil belajar adalah kemampuan-kemampuan yang dimiliki oleh siswa setelah menerima pengalaman belajarnya ketika suatu proses belajar berakhir maka siswa akan memperoleh hasil belajar mereka. Hasil belajar yang mereka peroleh biasanya berupa nilai.

Berdasarkan observasi awal yang dilakukan pada 23 Januari 2019, rendahnya hasil belajar pada mata pelajaran ekonomi juga terjadi pada SMA Kristen 1 Salatiga di kelas X IPS 3, rata-rata nilai yang dicapai sebesar 74,14 dengan presentase ketuntasan $60,71 \%$. Berdasarkan data yang diperoleh bisa dilihat bahwa sebanyak lebih dari $50 \%$ belum mencapai KKM, padahal KKM yang sudah ditetapkan di SMA Kristen 1 Salatiga yaitu 75 tergolong standar. Salah satu penyebab hasil belajar siswa kelas X IPS 3 yang rendah adalah sebagai berikut:

1. Kurangnya minat dan motivasi belajar siswa dalam mengikuti pelajaran.

2. Pada kegiatan pembelajaran, Guru kurang maksimal dalam menggunakan media dan alat pembelajaran yang inovatif.

3. Penjelasan materi lebih berpusat pada guru, sehingga kurang terciptanya keaktifan siswa.

4. Fasilitas sekolah yang kurang memadai dalam kegiatan pembelajaran.

Kurangnya motivasi belajar siswa dimana ketika motivasi belajar siswa rendah maka hal itu juga akan menyebabkan hasil belajar juga rendah (Purwanto, 2012). Penyebab rendahnya motivasi belajar siswa di X IPS 3 adalah sebagai berikut:

1. Kemauan siswa

2. Kondisi siswa

3. Kondisi lingkungan siswa. 
Menurut (Sutarsan, 2013) agar pembelajaran dapat tercapai dengan baik, pendidik harus mempunyai kemampuan dalam menentukan pendekatan pembelajaran. Pendekatan pembelajaran adalah suatu pandangan guru terhadap siswa dalam menilai, menentukan sikap dan perbuatan yang dihadapi dengan harapan dapat memecahkan masalah dalam mengelola kelas yang nyaman dan menyenangkan dalam proses pembelajaran. Menurut (Mulyati \& Pratama, 2019) metode pembelajaran adalah caracara menyajikan materi pelajaran yang dilakukan oleh pendidik agar terjadi proses pembelajaran pada diri siswa dalam upaya untuk mencapai tujuan pembelajaran. Dalam pemilihan metode pembelajaran, guru harus melihat keadaan siswa dan kelas, karena akan sangat mempengaruhi tujuan pembelajaran. Maka dari itu guru diharapkan dapat memilih metode pembelajaran yang tepat sehingga dapat meningkatkan motivasi belajar siswa supaya hasil pembelajaran juga baik.

Menurut (Andreawan, 2013) metode pembelajaran kooperatif adalah metode pembelajaran yang secara sadar dan mengembangkan interaksi yang saling tenggang rasa untuk menghindari ketersinggungan dan kesalahpahaman yang dapat menimbulkan kesalahpahaman. Hasil belajar yang juga diperoleh dari metode pembelajaran kooperatif bukan hanya nilai-nilai akademis saja tetapi juga memberikan nilai rasa tanggung jawab saling menghargai, saling menghormati, saling memberi, saling membutuhkan dengan keberadaan orang disekitar kita.

Dari permasalahan yang telah diuraikan, peneliti tertarik untuk menerapkan metode pembelajaran kooperatif model jigsaw untuk meningkatkan motivasi dan hasil belajar siswa.

\section{Metode Penelitian}

Penelitian yang dilaksanakan adalah penelitian tindakan kelas (PTK). Sebuah penelitian yang dilaksanakan di dalam kelas dengan target mengubah atau mengembangkan taraf pembelajaran di dalam kelas. Menurut (Rikardi \& Fikri, 2013) penelitian tindakan kelas yaitu penelitian tindakan yang diterapkan di kelas untuk memperbaiki dengan tujuan untuk membenahi mutu pembelajaran di kelas. Penelitian tindakan kelas (PTK) terdiri dari dua siklus, yang dimana setiap siklus terdiri dari empat tahapan yaitu perencanaan, tindakan, observasi dan refleksi. Penelitian dilakukan di SMA Kristen 1 Salatiga yang terletak di Mangunsari, Sidomukti, Kota Salatiga pada bulan Juni 2019. Target atau subjek penelitian ini adalah seluruh siswa kelas X IPS 3 SMA Kristen 1 Salatiga yang berjumlah 28 orang.

Prosedur penelitian tindakan yang dipakai dalam penelitian ini adalah model yang dicetuskan Stepen, Shike dan Snapp. Alasan peneliti menggunakan model tersebut karena model penelitian ini sesuai dengan penerapan metode pembelajaran model jigsaw yang akan dilakukan di dalam kelas. Model Stepen, Shike, dan Snapp terdiri atas beberapa komponen yaitu perencanaan tindakan, pelaksanaan tindakan, observasi dan refleksi. Teknik analisis data yang dipakai ialah deskriptif kuantitatif. Target dari analisis ini yaitu menggambarkan aktivitas siswa selama kegiatan pembelajaran. Analisis deskriptif dipakai untuk menghitung hasil belajar. Peningkatan hasil belajar 
bisa diamati dari nilai tes yang dilakukan di awal dan akhir pembelajaran juga angket yang diberikan di akhir pembelajaran. Peningkatan hasil belajar juga bisa dilihat dari nilai peserta didik yang telah memenuhi KKM.

\section{Hasil dan Pembahasan}

Hasil penelitian ini melingkupi motivasi serta hasil belajar siswa. Hasil dari meningkatkan motivasi siswa didapat dari lembar angket yang diisi oleh siswa. Hasil belajar diperoleh dari hasil tes individu pada pokok bahasan manajemen dan koperasi menggunakan metode pembelajaran kooperatif model jigsaw (Hanifah, 2016). Pada setiap siklus, pelaksanaan tindakan dilakukan dua kali pertemuan. Pertemuan pertama dilakukan selama satu jam pelajaran dan pertemuan kedua dilakukan selama dua jam pelajaran, dimana satu jam pelajaran sama dengan empat puluh lima menit. Hasil penelitian menggunakan metode pembelajaran kooperatif dengan model jigsaw diperoleh data sebagai berikut:

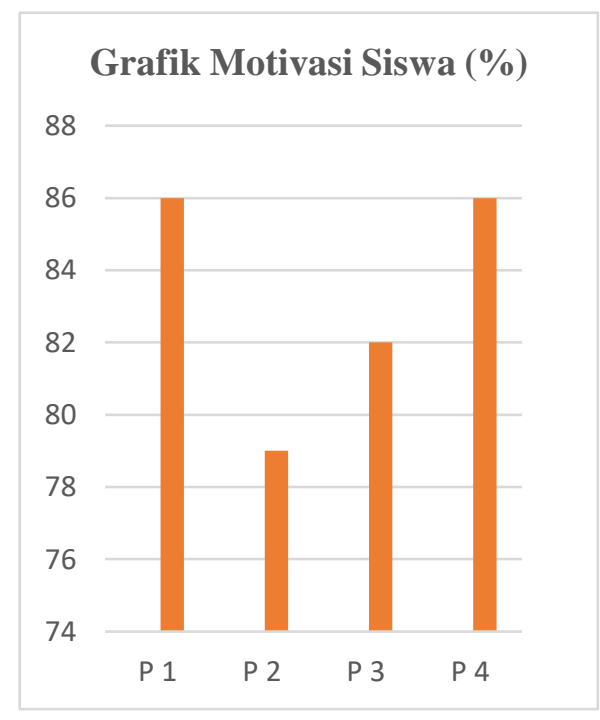

Grafik 1

Hasil Motivasi Siswa pada Siklus I

Hasil motivasi siswa yang diukur dalam bentuk pengisian angket, kelas X IPS 3 SMA Kristen 1 Salatiga dapat dilihat pada grafik 1, diperoleh sebanyak 24 dari 28 siswa menyatakan suka dengan pembelajaran jigsaw. Mereka merasa tertarik, dan bisa belajar lebih baik dan lebih mudah memahami materi yang diajarkan. Sebanyak 22 dari 28 siswa juga menyatakan hasil belajar mereka bisa lebih baik karena berdiskusi dengan teman dan termotivasi untuk belajar. Sebanyak 23 dari 28 siswa menyatakan bahwa mereka lebih memahami materi, dan sebanyak 24 dari 28 menyatakan hasil belajar mereka menjadi lebih baik. 
Ester Fajarita Kristanti

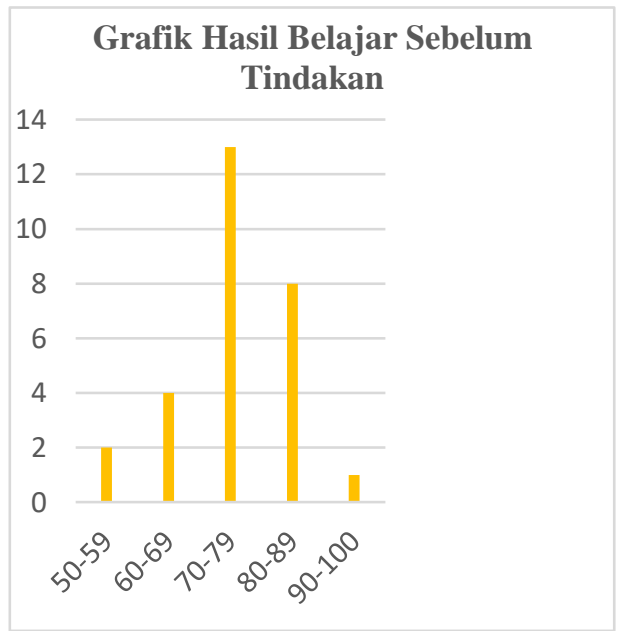

Grafik 2

Hasil Belajar Sebelum Tindakan

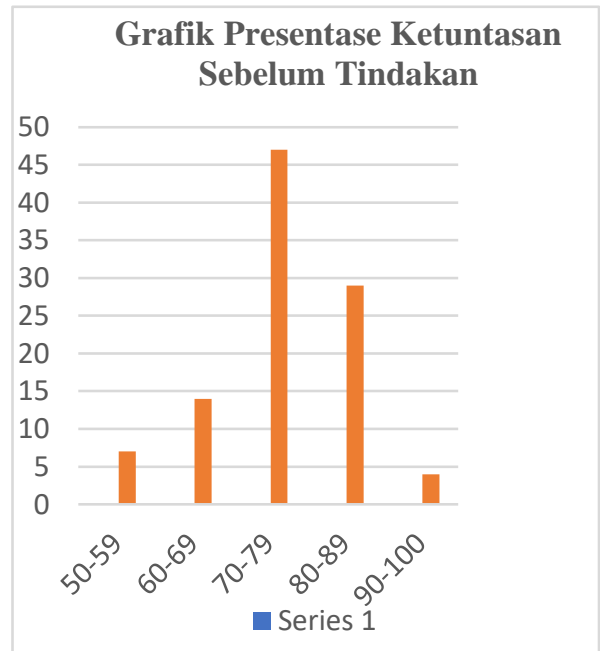

Grafik 3

Presentase Ketuntasan Sebelum Tindakan

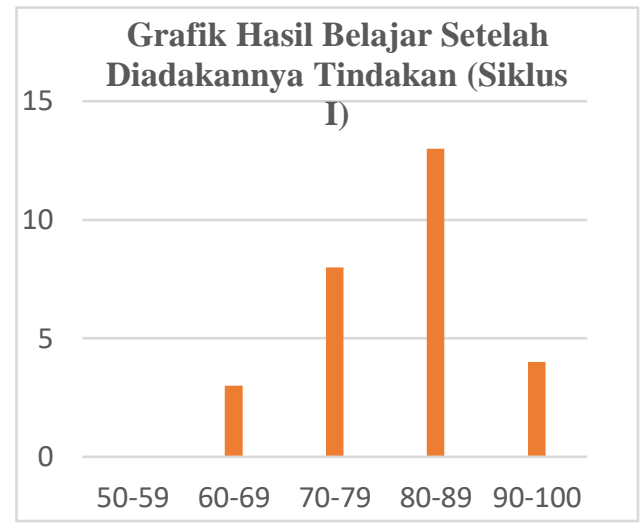

Grafik 4

Hasil Belajar Sesudah Diadakan Tindakan (Siklus I) 




Grafik 5

Presentase Ketuntasan Hasil Belajar Sesudah Tindakan

Pembahasan dalam penelitian ini merupakan hasil observasi selama penelitian. Penelitian tindakan kelas ini dilaksanakan untuk kemudian dilakukan refleksi secara keseluruhan pada setiap siklusnya. Pembelajaran dalam penelitian tindakan kelas ini, mengambil mata pelajaran ekonomi dengan pokok bahasan manajemen dan koperasi. Materi pelajaran ini mengenai konsep manajemen dan pengoperasian. Dalam perekonomian Indonesia, hasil observasi awal yang dilakukan di kelas X IPS 3 SMA Kristen 1 Salatiga menunjukkan masih ada 11 dari 28 siswa yang nilainya masih dibawah KKM yang telah ditentukan yaitu 75. Cara penyelesaian dari permasalahan ini yaitu menerapkan metode pembelajaran koperatif model jigsaw.

Selama pelaksanaan penelitian dengan menggunakan metode pembelajaran kooperatif model jigsaw pada pelajaran ekonomi dengan pokok bahasan manajemen dan koperasi dari sebelum diadakannnya tindakan sampai setelah diadakannya tindakan yaitu siklus I terjadi perubahan dalam proses pembelajaran kearah yang lebih baik.

Perubahan ini bisa dilihat dari hasil belajar siswa. Ketuntasan belajar sebelum diterapkannya metode pembelajaran model jigsaw dan sesudah diterapkannya model tersebut. Hasil analisis terhadap hasil belajar siswa menunjukkan bahwa dari sebelum diadakannya tindakan sampai dengan telah diadakannya tindakan terjadi peningkatan. Rata-rata hasil belajar siswa sebelum diadaknnya tindakan sebesar 74,14 serta presentase ketuntasan belajar sebesar 60,71 kemudian setelah diadakannya tidakan yaitu siklus I rata-rata hasil belajar sebesar 80,92 dengan ketuntasan belajar sebesar 82,14\%.

Hal tersebut menujukkan bahwa timbul peningkatan pengetahuan siswa pada materi yang dipelajari lewat kegiatan pembelajaran yang sudah dilaksanakan siswa. Hal ini menunjukkan bahwa ketuntasan belajar yaitu lebih dari atau sama dengan $75 \%$. Hal ini berarti dengan diterapkannya metode pembelajaran kooperatif model jigsaw, motivasi dan hasil belajar mengalami peningkatan.

Hasil observasi guru pada siklus I sebesar 87,27\%. Dari data tersebut telah menujukkan kinerja guru yang sudah cukup baik. Berdasarkan hasil penelitian tersebut, maka bisa dinyatakan keunggulan metode pembelajaran koperatif model jigsaw pada 
mata pelajaran ekonomi dengan pokok bahasan manajemen dan koperasi yaitu dapat meningkatkan motivasi dan hasil belajar siswa sebagai berikut:

1. Metode pembelajaran kooperatif model jigsaw dapat meningkatkan kerjasama antar siswa karena dalam pembelajaran ini siswa dituntut untuk memberikan dan mengajarkan materi kepada teman kelompoknya.

2. Metode pembelajaran kooperatif model jigsaw dapat meningkatkan motivasi dan hasil pembelajaran siswa dalam mata pelajaran ekonomi dengan pokok bahasan konsep manajemen dan koperasi.

Penerapan metode pembelajaran kooperatif model jigsaw dapat meningkatkan motivasi belajar siswa, bisa dilihat dari 24 dari 28 siswa $(85,71 \%)$ menyatakan suka dengan metode pembelajaran kooperatif model jigsaw, 22 dari 28 siswa $(78,57 \%)$ menyatakan belajar menjadi lebih baik, 23 dari 28 siswa $(82,14 \%)$ menyataakn dengan metode pembelajaran kooperatif model jigsaw dapat lebih memahami materi, 22 dari 28 siswa $(85,71 \%)$ menyatakan dengan pembelajaran kooperatif model jigsaw, mereka mendapatkan hasil yang lebih baik.

Pembelajaran dengan menerapkan metode pembelajaran kooperatif model jigsaw dapat dijadikan sebagai salah satu alternatif untuk meningkatkan motivasi serta pemahaman siswa terhadap mata pelajaran sehingga pembelajaran dapat berlangsung menjadi lebih baik dan tujuan yang dicapai menjadi lebih optimal. Penerapan metode pembelajaran kooperatif model jigsaw dapat meningkatkan motivasi dan hasil belajar siswa dalam mata pelajaran ekonomi dengan pokok bahasan manajemen dan koperasi kelas X IPS 3 SMA Kristen 1 Salatiga.

Seperti yang terdapat pada penelitian terdahulu yaitu penerapan metode pembelajaran kooperatif untuk meningkatkan hasil belajar siswa yang dilaksanakan di SMK Negeri 1 Salatiga oleh Rezky Yuanita pada tahun 2012 dengan pokok bahasan membukukan jurnal umum ke buku besar dinyatakan berhasil dalam pelaksanaanya. Hal ini menunjukkan penerapan metode pembelajaran kooperatif berpengaruh dalam meningkatkan motivasi dan hasil belajar siswa.

Pembelajaran dengan menerapkan metode pembelajaran kooperatif model jigsaw juga bermanfaat bagi masyarakat dan perkembangan ilmu pengetahuan. Bagi guru penelitian ini, dengan menerapkan metode pembelajaran model jigsaw ini, mampu memfasilitasi peserta didik dalam mempelajari materi pelajaran dengan lebih mudah. Bagi siswa hasil penelitian yang sudah dilakukan diharapkan bisa meningkatkan motivasi dan hasil belajar siswa dengan menerapkan metode pembelajaran siswa. Bagi peneliti diharapkan mampu menerapkan metode metode pembelajaran tertentu dan peneliti mempunyai pengetahuan tentang media pembelajaran yang sesuai dan bagi perkembangan ilmu pengetahuan, diharapkan hasil penelitian dengan menerapkan metode pembelajaran ini bisa menaikkan motivasi dan hasil belajar anak didik serta kegiatan pembelajaran yang dilaksanakan oleh guru di sekolah. Sekolah juga bisa menerapkan dan melakukan metode pembelajaran yang lebih beragam lagi.

\section{Kesimpulan}


Penerapan metode pembelajaran kooperatif model jigsaw terhadap motivasi dan hasil belajar telah dilaksanakan. Selama kegiatan berlangsung dilakukan beberapa tindakan yaitu perencanaan, tindakan, refleksi dan evaluasi. Berdasarkan pembahasan dan analisis data, maka dapat disimpulkan bahwa penerapan metode kooperatif model jigsaw dapat meningkatkan motivasi dan hasil belajar siswa. Hasil penelitian ini menunjukkan bahwa penerapan metode pembelajaran model jigsaw dapat meningkatkan motivasi dan hasil belajar siswa. Hal tersebut ditandai setelah diadakannya siklus I, motivasi belajar siswa menigkat, siswa menjadi lebih memahami materi dan mendapatkan hasil yang lebih baik. Hasil belajar siswa juga mengalami peningkatan, yaitu ditandai dengan rata- rata hasil belajar yang dicapai yaitu sebesar 80,92 dengan presentase ketuntasan belajar sebesar $82,14 \%$ dari yang sebelumnya hanya mencapai 74,14 dengan presentase ketuntasan sebesar $60,71 \%$. 


\section{BIBLIOGRAFI}

Andreawan, G. A. (2013). Model Kooperatif Gi Untuk Meningkatkan Aktivitas Dan Hasil Belajar Teknik Bola Basket. Jurnal Pendidikan Jasmani, Olahraga Dan Kesehatan Undiksha, 1(3). Google Scholar

Anwar, M. (2015). Filsafat Pendidikan. Kencana. Google Scholar

Aunurrahman, A., Hamied, F. A. H., \& Emilia, E. (2017). Exploring The Tertiary Efl Students'academic Writing Competencies. Indonesian Journal Of Applied Linguistics, 7(1), 72-79. Google Scholar

Hanifah, N. (2016). Perbedaan Hasil Belajar Materi Elastisitas Melalui Model Pembelajaran Kooperatif Tipe Jigsaw Dan Student Archievment Division (Stad) Siswa Kelas X Sma Negeri 5 Banda Aceh. Jurnal Ilmiah Mahasiswa Pendidikan Fisika, 1(3). Google Scholar

Huda, M., \& Pembelajaran, M. M. P. D. (2014). Pustaka Pelajar. Yogyakarta. Google Scholar

Mulyati, A., \& Pratama, D. F. (2019). Meningkatkan Motivasi Belajar Siswa Menggunakan Metode Cooperative Script Dalam Pembelajaran Bahasa Indonesia. Collase (Creative Of Learning Students Elementary Education), 2(6), 231-234. Google Scholar

Noor, T. (2018). Rumusan Tujuan Pendidikan Nasional Pasal 3 Undang-Undang Sistem Pendidikan Nasional No 20 Tahun 2003. Wahana Karya Ilmiah Pendidikan, 3(01). Google Scholar

Parnawi, A. (2019). Psikologi Belajar. Deepublish. Google Scholar

Purwanto, R. (2012). Peningkatan Motivasi Dan Hasil Belajar Siswa Pada Kompetensi Sistem Koordinasi Melalui Metode Pembelajaran Teaching Game Team Terhadap Siswa Kelas Xi Ipa Sma Smart Ekselensia Indonesia Tahun Pelajaran 2010-2011. Jurnal Pendidikan Dompet Dhuafa, 2(01), 55-65. Google Scholar

Rikardi, T., \& Fikri, H. (2013). Peningkatan Aktivitas Dan Keterampilan Menulis Siswa Kelas Vii Melalui Penerapan Metode Pembelajaran Kooperatif Tipe Jigsaw Di Smp Negeri I Solok Selatan. Abstract Of Undergraduate, Faculty Of Education, Bung Hatta University, 2(6). Google Scholar

Rohaeni, S. (2020). Pengembangan Sistem Pembelajaran Dalam Implementasi Kurikulum 2013 Menggunakan Model Addie Pada Anak Usia Dini. Instruksional, 1(2). Google Scholar

Saputra, W. N. E. (2016). Pendidikan Kedamaian: Peluang Penerapan Pada Pendidikan Tingkat Dasar Di Indonesia. Jurnal Care (Children Advisory Research And Education), 3(3), 88-94. Google Scholar 
Penerapan Metode Pembelajaran Model Jigsaw Terhadap Motivasi Dan Hasil Belajar

Sardiman, A. M. (2014). Posisi Ips, Tantangan Masa Depan, Dan Alternatif Baru. Socia: Jurnal Ilmu-Ilmu Sosial, 11(2). Google Scholar

Sutarsan, S. (2013). Peningkatan Keaktifan Belajar Pendidikan Agama Islam Melaui Model Pembelajaran Kooperatif Tipe Stad Siswa Kelas Vii Di Smp Assirajiyah Menur Mranggen Demak. Fakultas Agama Islam Unissula. Google Scholar

Syamsi, I. (2010). Pendidikan Luar Sekolah Sebagai Pemberdaya Dalam Masyarakat. Diklus, 14(1). Google Scholar

\section{Copyright holder :}

Ester Fajarita Kristanti (2021)

First publication right :

Journal Syntax Admiration

This article is licensed under:

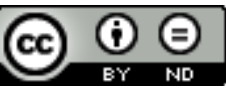

